\title{
Myocardial sarcoidosis
}

\author{
P. Ghosh, H. A. Fleming, G. A. Gresham, and P. G. I. Stovin \\ From the University of Cambridge, Addenbrooke's Hospital and Papworth Hospital, Cambridge
}

Six probable cases of myocardial sarcoidosis which came to necropsy at Cambridge are reported. The presenting clinical features, pathological changes, and possible management are discussed. It is suggested that myocardial sarcoidosis may not be as rare as it would seem from the single well-documented case reported from the British Isles. Possibility of involvement of the myocardium should be borne in mind in any patient with sarcoidosis who develops persistent arrhythmia or in any case of heart block where the cause is obscure.

Ernest Besnier in 1889 first described sarcoidosis as a dermatological entity, but it was not until I9I4 that the modern concept of sarcoidosis as a systemic granulomatosis was postulated by Schauman. In 1929, Bernstein, Konzlemann, and Sidlick first observed sarcoid lesions of the epicardial and superficial layers of the myocardium, and Gentzen in I937 reported the first death attributable to myocardial sarcoidosis. Subsequent sporadic case reports appeared, and in 1960 Porter reviewed the published material and added one case of his own. Forbes and Usher (1962) reported the first well-documented fatal case of myocardial sarcoidosis from the British Isles, and Scadding (1967) noticed clinical features suggesting myocardial sarcoidosis in only 2 out of 275 cases in his series, the evidence being no more than circumstantial. We report here 6 cases of proved myocardial sarcoidosis from the necropsy studies at Cambridge, and in 4 out of 6 cases death was attributable to the involvement of the myocardium.

\section{Case reports}

Case I A 59-year-old woman suddenly collapsed and died. She was seen by one of us (H.A.F.) 8 years previously with supraventricular tachycardia following uterine curettage. When the rate was controlled she was found to have left bundle-branch block followed by complete heart block 6 years later. At that time she was treated with a long-acting isoprenaline but the treatment had to be stopped because of multiple ventricular premature beats. Necropsy showed the heart to be covered by numerous small tough, grey-white nodules mainly in the lateral and posterior wall of the left ventricle, extending into the ventricular

Received Is September 1971. septum, and these histologically were typical of sarcoid granuloma. Histological examination also showed lesions in the right ventricle and left atrium. There were also a few similar granulomas in the lungs and liver.

Case 2 A 4I-year-old woman collapsed and died. She was a known case of multiple sclerosis but had no previous history of cardiac illness. Necropsy revealed a granulomatous nodule at the junction of endocardium and myocardium in the left atrium which contained lymphocytes, histiocytes, and giant cells. There was no evidence of granulomatous disease elsewhere.

Case 3 A 37-year-old man collapsed and died. This man had lymphadenopathy as a child and was found to have iritis 2 years previously. Necropsy showed small areas of grey-white fibrosis on the cut surface of the left ventricle close to the septum at the junction of the middle and lower thirds. Histologically, there were a few areas of chronic inflammatory cellular infiltration in the left ventricle and there was also infiltration by giant cells in one of these areas on the anterior wall of the left ventricle near the septum. There was an enlarged lymph node in the deep cervical region which contained typical sarcoid granulomas. There was no evidence of pulmonary disease.

Case 4 A 55-year-old man was found dead at 9.0 p.m. in a hospital bed. This man had been a known case of sarcoidosis for 13 years, and an electrocardiogram showed partial right bundlebranch block 2 years before death when he was investigated for progressive dyspnoea. He had been on steroids for some time and was admitted with haematemesis for which he needed an emergency operation. Eight weeks later he was noted to have a few ectopic beats and 2 days later he was found dead. Necropsy showed extensive infiltration by sarcoid granulomas of the left ventricle, right atrium, lymph nodes, spleen, and pleura. 
Case 5 A 50-year-old woman was diagnosed as a case of sarcoidosis for 20 years. Twelve years before she had an attack of iridocyclitis and also had a positive Kveim's test. She was admitted to hospital with progressive dyspnoea and an electrocardiogram showed right axis deviation, $P$ pulmonale, and atrial ectopics. She deteriorated in spite of intensive medical treatment and died. Necropsy showed hyaline scars in the atrioventricular node consistent with a late stage of sarcoidosis.

Case 6 A 38-year old man was a known case of aortic valve disease from the age of 18 . Six months before his death he had replacement of the aortic valve which, in addition to calcification, showed a granuloma consistent with sarcoidosis. There were no alcohol-acid-fast bacilli in the granuloma. Six months later he was readmitted with diphtheroid subacute bacterial endocarditis and died as a result of prolapse and rupture of the prosthetic valve. Necropsy showed sarcoid granulomas in lungs and spleen; there was mild focal interstitial myocarditis with infiltration of lymphocytes and plasma cells, but there were no definite granulomata.

\section{Discussion}

Incidence Fatal myocardial sarcoidosis is relatively uncommon, the necropsy incidence being higher than that detected clinically. Ricker and Clark (1949) found sarcoid involvement of the myocardium in 2 out of 22 cases whereas none of Scadding's (I967) II fatal cases where a complete necropsy was done had any myocardial involvement. Mayock et al. (1963) analysed I45 patients with a review of 9 series from the published papers and found that 19 out of 145 cases $(13 \%)$ had some kind of cardiac abnormality and 5.1 per cent of the combined series showed some intrinsic cardiac abnormality. Longcope and Freiman (1952) reported the involvement of the heart in 20 per cent of the necropsy series, which is certainly higher than the clinical series (Mayock et al., 1963). Bashour et al. (1968) reported 2 cases at necropsy giving an incidence of 0.025 per cent of the total necropsies.

The sex incidence in our series is equally divided between male and female patients, similar to the collected cases of Bashour et al. (1968). The age of our patients varied from 37 to 60 years, similar to the published reviews. There is an increased incidence in Negroes from the reports in the American literature (Rajasenan and Cooper, 1969) whereas all our patients were Caucasian.

Clinical aspects The clinical presentation of myocardial sarcoidosis may be described under the following headings. (a) Disturbances of rhythm. (b) Sudden death. (c) Congestive cardiac failure with or without cardiomegaly. (d) Miscellaneous.

Disturbances of rhythm are the most common presenting feature of myocardial sarcoidosis. Bashour et al. (1968) reviewed the published reports and found 17 of 35 reported cases had disturbances of rhythm. Complete heart block is most frequently reported (Porter, 1960; Bashour et al., 1968). This can often lead to syncopal attacks which might be the dominant presenting feature (Botti and Young, 1959; Phinney, 196r; Rajasenan and Cooper, 1969). Other conduction disturbances in the form of first-degree heart block

TABLE Summary of clinical details of 6 patients

\begin{tabular}{|c|c|c|c|c|c|c|}
\hline \multicolumn{3}{|c|}{$\begin{array}{l}\text { Case No., age, } \\
\text { and sex }\end{array}$} & \multirow{2}{*}{$\begin{array}{l}\text { Clinical illness } \\
\begin{array}{c}\text { Left bundle-branch block, I960; com- } \\
\text { plete heart block, I } 966\end{array}\end{array}$} & \multirow{2}{*}{$\begin{array}{l}\text { Sudden or } \\
\text { unexpected } \\
\text { death }\end{array}$} & \multirow{2}{*}{$\begin{array}{l}\text { Signs of } \\
\text { congestive } \\
\text { cardiac } \\
\text { failure }\end{array}$} & \multirow{2}{*}{$\begin{array}{l}\text { Electrocardiogram } \\
\text { Complete heart block }\end{array}$} \\
\hline I & 59 & $\mathbf{F}$ & & & & \\
\hline 2 & $4 I$ & $\mathbf{F}$ & $\begin{array}{l}\text { Disseminated sclerosis; no cardiac } \\
\text { symptoms }\end{array}$ & + & - & - \\
\hline 3 & 37 & $\mathbf{M}$ & $\begin{array}{l}\text { Iritis in 1953; gland trouble as a child; } \\
\text { vague chest pain, I year }\end{array}$ & + & - & - \\
\hline 4 & 55 & $\mathbf{M}$ & $\begin{array}{l}\text { Known case of sarcoid since 1956; pro- } \\
\text { gressive dyspnoea and heart failure }\end{array}$ & + & + & $\begin{array}{l}\text { Prolonged PR, intraven- } \\
\text { tricular conduction } \\
\text { defect }\end{array}$ \\
\hline 5 & 50 & $\mathbf{F}$ & $\begin{array}{l}\text { Iridocyclitis in 1953; sarcoid diagnosed } \\
\text { in 1961; progressive dyspnoea }\end{array}$ & - & + & $\begin{array}{l}\text { Right axis deviation, } P \\
\text { pulmonale; atrial } \\
\text { ectopic }\end{array}$ \\
\hline 6 & 38 & $\mathbf{M}$ & $\begin{array}{l}\text { Congenital aortic stenosis; death due to } \\
\text { rupture of prosthetic aortic valve after } \\
\text { infection }\end{array}$ & - & + & $\begin{array}{l}\text { Left ventricular hyper- } \\
\text { trophy; ventricular } \\
\text { ectopic, prolonged PR }\end{array}$ \\
\hline
\end{tabular}


and intraventricular conduction defects can occur (Longcope and Freiman, 1952; Ryrie, 1954; Forbes and Usher, 1962 ; Peison, 1966). In our series of 6 patients, I had left bundlebranch going on to complete heart block 6 years later; 2 had first-degree heart block, and one in addition had intraventricular conduction defects. Bashour et al. (1968) in reviewing the incidence of rhythm disturbance in myocardial sarcoidosis found I4 episodes of complete heart block, 2 episodes each of firstdegree heart block and intraventricular conduction defects, and I case of right bundlebranch block in 35 patients. Cardiac arrhythmia is the second most common abnormality. Ventricular tachycardia is most frequently reported (Johnson and Jason, 1944; Powell, 1954; Bashour et al., 1968; Chamovitz, Culley, and Carlson, 1962; Rajasenan and Cooper, 1969). Multifocal ventricular premature systoles may often be present (Bashour et al., 1968; Ferrans et al., 1965). The atrial arrhythmias are less frequently reported and consist of atrial fibrillation (Pascoe, 1964), atrial flutter (Yesner and Silver, I95I ; Deneberg, 1965), and atrial ectopics (Nissen and Berte, I964). Sinus tachycardia has occasionally been re- ported (Chisholm, 1966; Peison, 1966). In our series one patient had atrial ectopics and one had ventricular ectopics.

Sudden death is common in myocardial sarcoidosis and has been reported in 50 per cent of cases (Kulka, 1950; Poon and Forbus, 1959;

- Porter, 1960; Adickes, Zimmerman, and Cardwell, 1951). Forbes and Usher (1962) in reviewing the published reports found 19 out of 25 cases were sudden or unexpected deaths. In our series, 4 out of 6 were found unexpectedly dead. Often in these cases, there had been no suspicion of myocardial involvement clinically.

- Congestive cardiac failure with or without cardiomegaly was seen in 14 out of 16 patients reviewed by Bashour et al. (I968). In Porter's series (1960) one-third of those dying from myocardial sarcoidosis had congestive cardiac failure. Of our 6 patients, 3 had evidence of congestive cardiac failure. The congestive - state was thought to be the result of diffuse myocardial involvement and was often associated with cardiac arrhythmias.

Electrocardiographic abnormalities simulating myocardial infarction due to extensive involvement of the myocardium may be seen. The electrocardiographic changes may vary from simple inversion of $T$ waves to significant $Q$ waves with the elevation of ST segments
(Gold and Cantor, 1959; Hines and Sancetta, 1963; Bashour et al., 1968). As only large extensive lesions are likely to produce electrocardiographic changes compatible with myocardial infarction, it is not surprising this is so uncommonly reported, for the lesions are often small nodules scattered in the myocardium.

Involvement of valves is rare and it is often difficult to decide whether it is due to coincidental rheumatic heart disease. Raftery, Oakley, and Goodwin (1966) reported a West Indian woman with acute mitral incompetence who also had florid sarcoidosis. At operation, the papillary muscles presented a white glazed appearance, and histology showed fibrosis between the muscle fibres with focal collections of lymphocytes, plasma cells, and histiocytes. The non-specificity of changes was thought to be due in part to prolonged steroid therapy. This particular woman later died in the United States and was found to have myocardial sarcoidosis (J. F. Goodwin, 1970, personal communication). One of our patients had actual granulomatous involvement of the aortic valve.

Pericardial involvement is comparatively rare. Pericardial effusion may appear, either due to primary involvement of the pericardium or secondary to congestive cardiac failure. Shiff, Blatt, and Colp (1969) reported the first case of recurrent pericardial effusion with

FIG. Pale sarcoid granulomas scattered through the cut surfaces of the left ventricle.

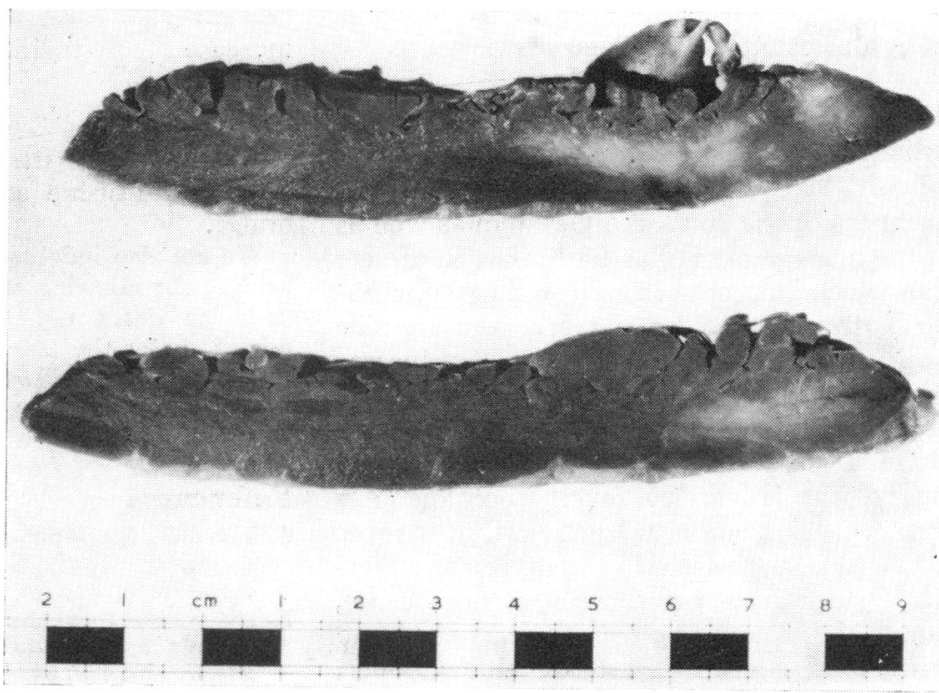


histological evidence of pericardial involvement, though pericardial effusion, thought to be due to sarcoidosis, was reported earlier by Bailey (1966) and Clark and Blount (1966) without definite histological evidence.

Pathology Myocardial sarcoidosis can easily be overlooked in the postmortem room because the lesions may, mistakenly, be attributed to ischaemic fibrosis. This should not happen because the areas of sarcoidosis are often erratically distributed in a pattern which does not follow any distribution of a major coronary vessel. Furthermore, diligent search may reveal lesions in the right ventricle and atria as well; the Figure illustrates the multiplicity of small lesions that may be found, and another important point is that they do not always occur in the endocardial parts but may be pericardial or deeply intramyocardial. This is another useful point of distinction from areas of ischaemic damage. A particular tendency of sarcoid lesions to involve the upper parts of the ventricular septum is another diagnostic feature.

One or more sarcoid granulomas do not, of course, clinch the diagnosis of sarcoidosis. Similar granulomas occur in a wide variety of conditions, and sarcoidosis is essentially a clinical diagnosis based upon the detection of lesions in several organs and reinforced by biopsy and a Kveim test. Our second and fifth cases are consequently not sharply defined examples of sarcoidosis.

Sarcoid granulomas of the heart are not always as sharply defined as those that occur in other organs such as lung and lymph nodes. They tend to be more diffuse and giant cells may not always be found, but the finding of such cardiac lesions in conjunction with more characteristic ones elsewhere in the body is enough to establish the diagnosis.

Management The management of myocardial sarcoidosis, when suspected in life, is difficult. Steroids are very often used in disturbances of the conducting system as well as for the management of arrhythmias. Complete heart block does not respond well to isoprenaline, atropine, molar lactate, or steroids (Smith, I964), and may be controlled by implanting a pacemaker (Johansen, 1966), though others (Phinney, 196I) have failed to obtain a good result with pacemakers. One patient was known to revert spontaneously from AV dissociation to sinus rhythm (Moyer and Ackerman, 1950). For arrhythmias, digitalis, quinidine, procainamide, lignocaine, though they should be tried, seem to have no permanent effect (Rajasenan and Cooper,
1969). These drugs should be used cautiously in view of the possibility of the patients developing heart block, and the importance of high calcium and low potassium should be borne in mind (Nissen and Berte, 1964). One of our patients was treated with steroids, but despite this the final outcome was fatal. Gold and Cantor (1959) reported the beneficial effects of steroids in their patients where the $Q$ wave disappeared with the return of ST and $T$ wave changes towards normal and a dramatic clinical improvement.

Beta adrenergic blocking drugs appear to have a place in controlling arrhythmia. One hopes that they may also reduce the incidence of sudden death. We (H.A.F.) are at present treating a man with myocardial involvement in sarcoidosis, who has multifocal ventricular premature systoles, with practolol. In a modest dose this appears to have drastically reduced the number of ectopic beats.

The poor therapeutic response could be due to the advanced stage of myocardial infiltration with possible resulting fibrosis, particularly at a critical site of involvement such as AV node. The discrete lesions are probably amenable to steroid therapy (Bashour et al., 1968). Nevertheless, in view of the serious prognosis, it is suggested that all patients with known sarcoidosis be given a trial of steroids, if a cardiac lesion is suspected.

These six fatal cases seen in one relatively small centre make us think that myocardial sarcoidosis may be more common than is recognized. We are in the course of carrying out a survey of cases seen by members of the Cardiac and Thoracic Societies of Great Britain, and the replies so far received indicate that many clinicians have never seen a case, nor have they thought of the diagnosis. Increased awareness in the future may well increase the incidence reported in this country.

P.G. is holder of the Grimshaw-Parkinson Research Studentship at the University of Cambridge.

We are also indebted to H.M. Coroner, Cambridge, for allowing us to publish the necropsy data for Cases I-3. Cases 4 and 6 were admitted under the late Dr. M. J. Greenberg and Mr. B. Milstein, respectively, and we are grateful to them for giving access to their notes.

\section{References}

Adickes, G. C., Zimmerman, S. L., and Cardwell, E. S., Jr. (I95I). Sarcoidosis with fatal cardiac involvement. Annals of Internal Medicine, 35, 898.

Bailey, R. R. (1966). Systemic sarcoidosis with pericarditis and pericardial effusion. New Zealand Medical fournal, 65, 704. 
Bashour, F. A., McConnell, T., Skinner, W., and Hanson, M. (1968). Myocardial sarcoidosis. Diseases of the Chest, 53, 413.

Bernstein, M., Konzlemann, F. W., and Sidlick, D. M. (1929). Boeck's sarcoid; report of case with visceral involvement. Archives of Internal Medicine, 44, $72 \mathrm{r}$.

Besnier, M. E. (I889). Lupus pernio de la face; synovites fongueuses (scrofulo-tuberculeuses) symétriques des extrémités supérieures. Annales de Dermatologie et Syphiligraphie, 10, 333.

Botti, R. E., and Young, F. E. (1959). Myocardial sarcoid, complete heart block and aortic stenosis. Annals of Internal Medicine, 51, $8 \mathrm{I}$ r.

Chamovitz, D. L., Culley, A. W., and Carlson, K. E. (1962). Cardiac sarcoidosis. Report of a case with paroxysmal ventricular tachycardia. Fournal of the American Medical Association, 182, 574.

Chisholm, J. C. (1966). Sarcoid cardiomyopathy. fournal of the National Medical Association, 58, 265.

Clark, E. J., and Blount, A. W. (1966). A fatal case of myocardial sarcoidosis. Fournal-Lancet, 86, 568.

Deneberg, M. (1965). Sarcoidosis of the myocardium and aorta. American fournal of Clinical Pathology, 43, 445 .

Ferrans, V. J., Hibbs, R. G., Black, W. C., Walsh, J. J., and Burch, G. E. (1965). Myocardial degeneration in cardiac sarcoidosis. American Heart fournal, 69, 159.

Forbes, G., and Usher, A. (1962). Fatal myocardial sarcoidosis. British Medical fournal, 2, 77I.

Gentzen, G. (1937). Úber Riesenzellengranulome bei zwei Fällen von Endocardfibrose. Beiträge zur pathologischen Anatomie, 98, 375.

Gold, J. A., and Cantor, P. J. (1959). Sarcoid heart disease: case with an unusual electrocardiogram. Archives of Internal Medicine, ro4, I01.

Hines, J. D., and Sancetta, S. M. (1963). Myocardial sarcoidosis simulating healed myocardial infarction. Ohio State Medical fournal, 59, 689.

Johansen, A. (1966). Isolated myocarditis versus myocardial sarcoidosis. Acta Pathologica et Microbiologica Scandinavica, 67, 15.

Johnson, J. B., and Jason, R. S. (I944). Sarcoidosis of the heart. American Heart fournal, 27, 246.

Kulka, W. E. (1950). Sarcoidosis of the heart: a cause of sudden and unexpected death. Circulation, $\mathbf{r}$, 772.

Longcope, W. T., and Freiman, D. G. (1952). A study of sarcoidosis. Medicine, 3I, I.

Mayock, R. L., Bertrand, P., Morrison, C. E., and Scott, J. H. (1963). Manifestation of sarcoidosis. Analysis of 145 patients, with a review of nine series selected from the literature. American fournal of Medicine, 35, 67.
Moyer, J. H., and Ackerman, A. J. (1950). Sarcoidosis: a clinical and roentgenological study of 28 cases. American Review of Tuberculosis, 6r, 299.

Nissen, A. W., and Berte, J. B. (1964). Cardiac arrhythmias in sarcoidosis. Archives of Internal Medicine, I13, 275.

Pascoe, H. R. (1964). Myocardial sarcoidosis. Archives of Pathology, 77, 299.

Peison, B. (1966). Sarcoidosis of the heart associated with myocarditis. Illinois Medical fournal, 130, 317.

Phinney, A. O. (1961). Sarcoid of the myocardial septum with complete heart block - report of 2 cases. American Heart fournal, 62, 270.

Poon, T. P., and Forbus, W. D. (1959). Sudden death due to myocardial sarcoidosis, with a comment on the etiology of sarcoid. Archives of Internal Medicine, 104, 771.

Porter, G. H. (1960). Sarcoid heart disease. New England fournal of Medicine, 263, 1350.

Powell, L. W., Jr. (1954). Sarcoidosis of the myocardium. North Carolina Medical fournal, 15, 28.

Raftery, E. B., Oakley, C. M., and Goodwin, J. F. (1966). Acute subvalvar mitral incompetence. Lancet, 2, 360.

Rajasenan, V., and Cooper, E. S. (1969). Myocardial sarcoidosis, bouts of ventricular tachycardia, psychiatric manifestations and sudden death. fournal of the National Medical Association, 6r, 306.

Ricker, W., and Clark, M. (1949). Sarcoidosis: a clinico-pathologic review of 300 cases. American fournal of Clinical Pathology, 19, 725.

Ryrie, D. R. (1954). Myocardial sarcoidosis. Proceedings of the Royal Society of Medicine, 47, 877.

Scadding, J. G. (1967). Sarcoidosis, p. 291. Eyre and Spottiswood, London.

Schauman, J. (I914). Sur le lupus pernio. Memoire presente en I Novembre I9I4 à la Societe Francaise de dermatologie Syphillographie pour le Prix Zambseo.

Shiff, A. D., Blatt, C. J., and Colp, C. (1969). Recurrent pericardial effusion secondary to sarcoidosis of the pericardium. New England fournal of Medicine, 28I, I4I.

Smith, W. P. (1964). Primary sarcoid heart disease. Fournal of the Florida Medical Association, 51, 652.

Yesner, R., and Silver, M. (1951). Fatal myocardial sarcoidosis. American Heart fournal, 41, 777.

Requests for reprints to Dr. P. Ghosh, Addenbrooke's Hospital, Trumpington Street, Cambridge, CB2 IQE. 